\title{
Sebaceous carcinoma of eyelid
}

\author{
Manoranjan Varshney, ${ }^{1}$ Kiran Alam, ${ }^{1}$ Mehar Aziz, ${ }^{1}$ Veena Maheshwari, ${ }^{1}$ Kavita Gaur, ${ }^{1}$ \\ SyedAli Raza Rizvi²
}

${ }^{1}$ Pathology Department, J. N. Medical College, Aligarh, Uttar Pradesh, India;

${ }^{2}$ Opthalmology Department, J. N. Medical College, Aligarh, Uttar Pradesh, India

Correspondence toDr Kavita Gaur, kavgaur@gmail.com

\section{Summary}

The authors are presenting here, a case of sebaceous carcinoma in a 50-year-old male who presented with 6-month history of a fungating mass in the right eye near medial canthus. Exenteration of eye was done, and a diagnosis of sebaceous carcinoma was made on histopathological examination.

\section{BACKGROUND}

Sebaceous carcinoma is one of the rare tumours of eyelid. Sometimes, only inflammation is seen in the tissue, and a small focus of carcinoma is seen as in our case. So careful search in multiple sections is needed to rule out small foci of carcinoma.

\section{CASE PRESENTATION}

A 50-year-old male presented with loss of vision and swelling at right upper eye lid for a duration of 6 months. General and systemic examinations were unremarkable. On ocular examination, no light perception was present. Local examination revealed a fungating mass over the right upper eyelid measuring $3 \times 3 \mathrm{~cm}$ near the medial canthus with damage to ocular tissue. Cornea was not identifiable. A clinical differential diagnosis of squamous cell carcinoma eyelid, preseptal cellulitis and lacrimal gland neoplasm was made. Exenteration of eye was done. Gross examination showed multiple greyish white soft tissue pieces, which altogether measuring $7 \times 3 \times 3 \mathrm{~cm}$. Largest piece was $4 \times 2 \times 2$ $\mathrm{cm}$ in size and smallest $1 \times 1 \times 1 \mathrm{~cm}$. Few pieces were skin covered. Microscopic examination revealed few small foci of tumour cells with surviving lobules of tumour cells with large vesicular nucleus, prominent nucleoli and foamy multivacuolated cytoplasm (figure 1A,B). Exuberant acute on chronic inflammation with foreign body giant cell

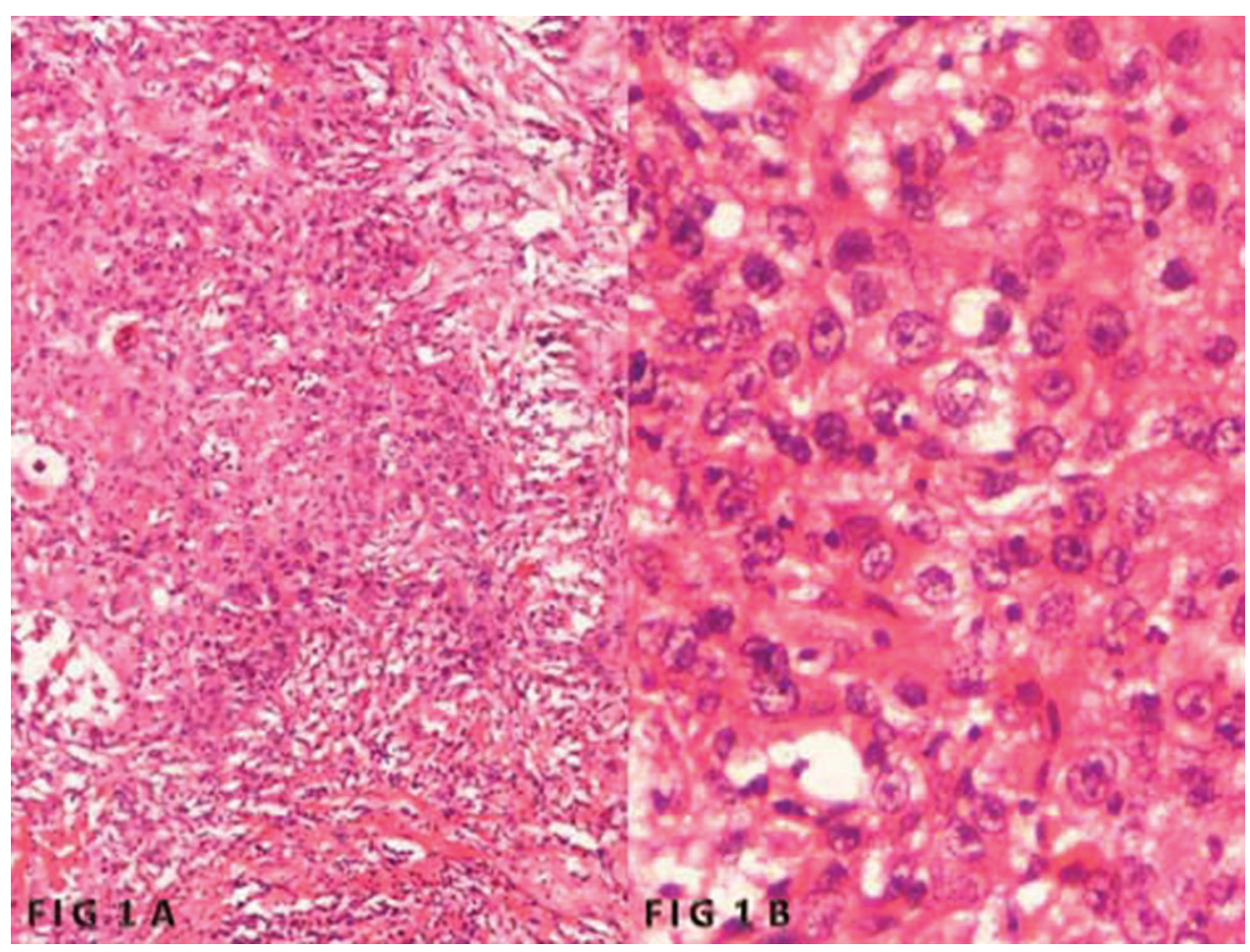

Figure 1 (A) Section showing small foci of tumour cells (H\&E $\times 50$ ). (B) Section showing tumour cells with large vesicular nucleus and multivacuolated cytoplasm $(\mathrm{H \& E} \times 500)$. 


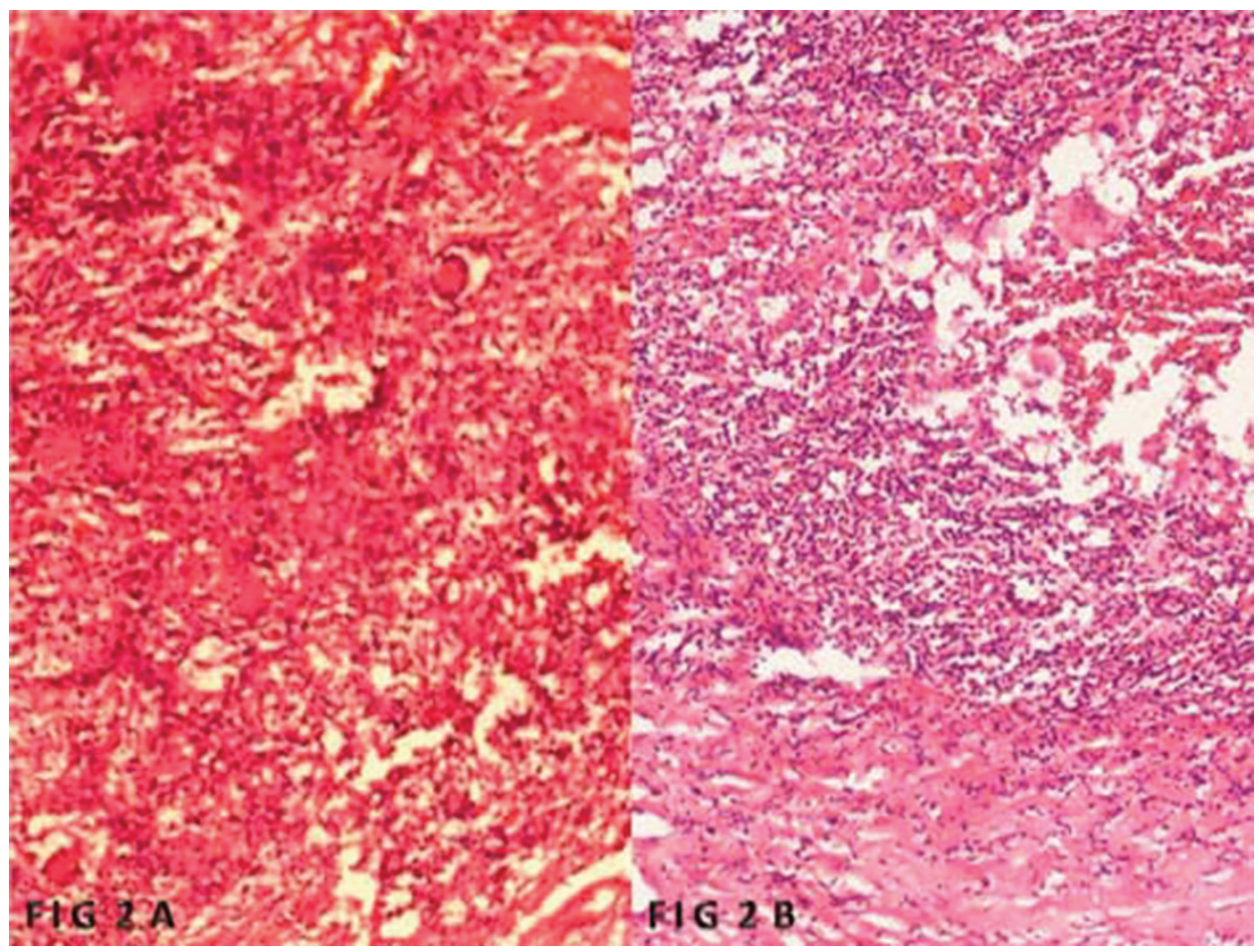

Figure 2 ( $A$ and $B)$ Section showing mononuclear cell infiltrate and giant cells $(\mathrm{H \& E} \times 50)$.

reaction and large areas of necrosis was seen (figure $2 \mathrm{~A}, \mathrm{~B}$ ). Skins, sclera with choroid and lacrimal gland tissue were free from tumour cells (figure $3 \mathrm{~A}-\mathrm{C}$ ). Optic nerve was free from tumour cells (figure $3 \mathrm{D}$ ). On the above finding, a diagnosis of sebaceous carcinoma was rendered. Patient is well till now (10 months since surgery).

\section{DIFFERENTIAL DIAGNOSIS}

- Basal cell carcinoma

- Squamous cell carcinoma

- Cutaneous horn

- Merkel cell carcinoma

- Pyogenic granuloma.

\section{TREATMENT}

Exenteration of eye was done.

\section{OUTCOME AND FOLLOW-UP}

Patient was discharged in good condition.

\section{DISCUSSION}

Sebaceous carcinoma is a rare and aggressive tumour, first described by Fuchs. It arises from the meibomian glands of the tarsal plate, from glands of Zeis or from sebaceous glands of the caruncle, eye brow or facial skin. ${ }^{1}$ It can be seen anywhere on the body where sebaceous gland exist. ${ }^{2-}$ ${ }^{4}$ Most common site of involvement is periocular area. ${ }^{5}{ }^{6} \mathrm{It}$ is commonly seen in sixth and seventh decade of life; however, it can be seen in any age group. It is the forth common malignancy after basal cell carcinoma, squamous cell carcinoma and melanoma, and comprises $1-5.5 \%$ of malignant tumours of eyelid. ${ }^{7-9}$ Aetiology is unknown till now, but few authors made a correlation with ionising radiation for other neoplasms, for example, cavernous haemangioma, barber's itch and retinoblastoma. ${ }^{10-12}$ Association with human papilloma virus and overexpression of TP53 is also reported by few authors. ${ }^{13}$ Clinical features include firm, painless, indurated mass or ulceration associated with loss of eyelashes. Clinical picture may mimic benign condition. Clinically, the differential diagnoses include basal cell carcinoma, squamous cell carcinoma, cutaneous horn, Merkel cell carcinoma, pyogenic granuloma and metastatic carcinoma of skin and chalazion. Cytomorphological features of sebaceous carcinoma include sheets, clusters and or singly scattered polygonal cells having centrally placed hyperchromatic nuclei and vacuolated cytoplasm. ${ }^{14} 15$ Microscopic examination shows lobules of cells with multivacuolated clear cytoplasm, raised nucleo-cytoplasmic ratio, clumped chromatin and prominent nucleoli. This is an aggressive tumour as the local recurrence and metastasis to other sites are very common. Liver, lung, bones and brain are the site of distant metastasis. ${ }^{7} 1617$ Surgical excision of tumour is the treatment of choice. Many surgeons prefer Mohs technique. In case of orbital involvement, treatment of choice is orbital exenteration as in our case. ${ }^{18}$ If orbit does not appear to be involved, the treatment of choice is excision of tumour along with 5-6 mm of normal tissue. ${ }^{19}$ Chemotherapy may be given preoperatively to reduce tumour size. Role of radiotherapy is unclear. Most of the surgeons give preference to surgical removal as the observed chances of recurrences following give preference to surgical excision of tumour and the observed chances of relapse following radiotherapy is quite high. ${ }^{20} \mathrm{Few}$ authors have reported good results with concurrent administration of radiotherapy with surgical removal. ${ }^{21}$ Radiotherapy may be given to those patients who refuse surgery. Features of poor prognosis include orbital invasion, poor 


\section{BMJ Case Reports}

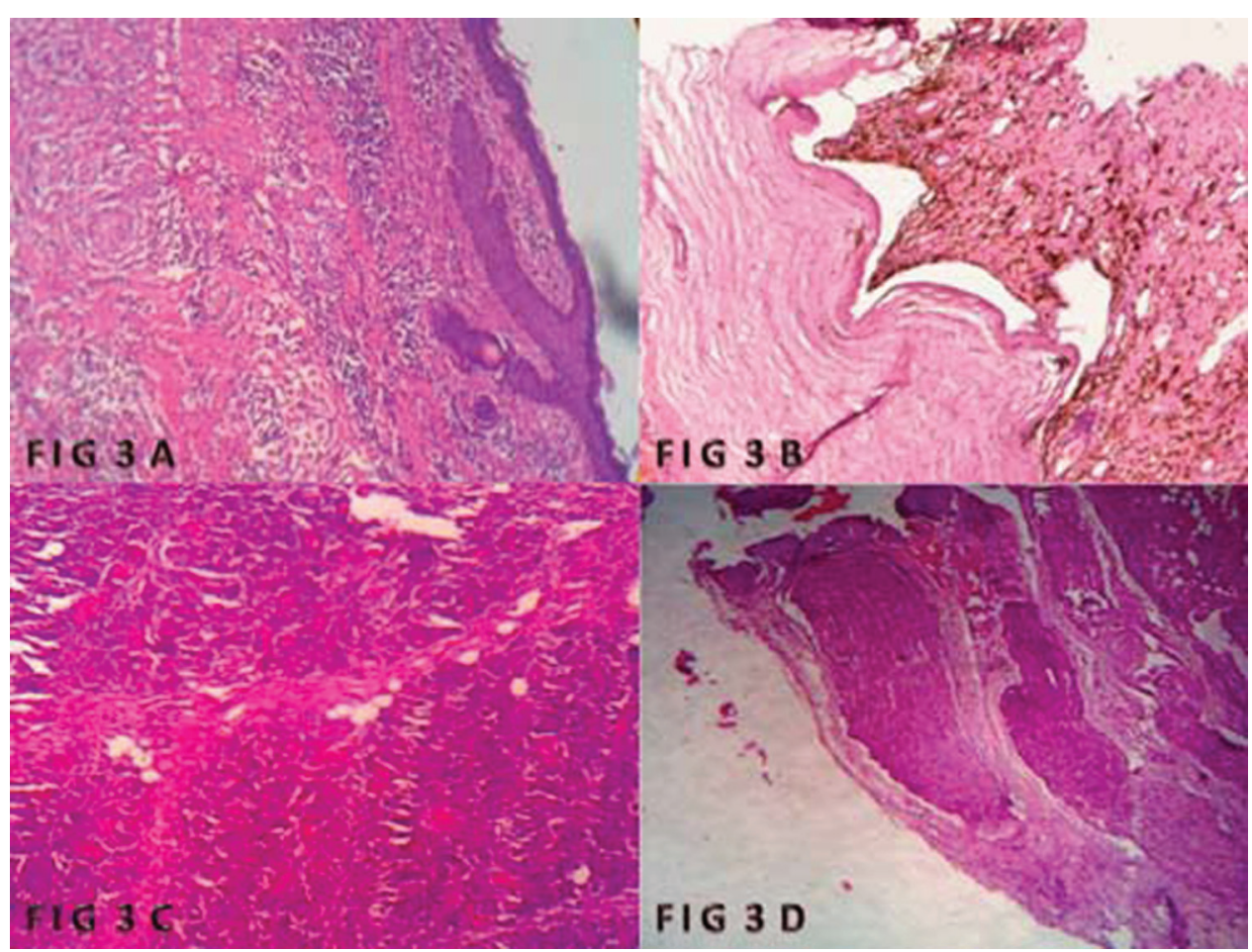

Figure 3 (A) Section showing stratified squamous epithelium and underlying mononuclear cell infiltrate $(H \& E \times 50)$. (B) Section showing sclera and choroid free from tumour cell $(H \& E \times 50)$. (C) Section of lacrimal gland with no tumour cell infiltration (H\&E $\times 50)$. (D) Section of optic nerve free from tumour cells $(H \& E \times 50)$.

differentiation, tumour diameter of more than $10 \mathrm{~mm}$ and lacrimal gland involvement. ${ }^{22} 23$ Tumours of the lower eye lid have been associated with better prognosis than those affecting the lower lid. ${ }^{24}$

\section{Learning points}

- This tumour can arise in any organ where sebaceous gland exists.

- Clinical presentation may mimic chalazion.

- It is an aggressive tumour, and any delay in diagnosis may result in early metastasis.

Competing interests None.

Patient consent Obtained.

\section{REFERENCES}

1. Kass LG, Hornblass A. Sebaceous carcinoma of the ocular adnexa. Surv Ophthalmol 1989;33:477-90.

2. Gomes CC, Lacerda JC, Pimenta FJ, et al. Intraoral sebaceous carcinoma. Eur Arch Otorhinolaryngol 2007;264:829-32.

3. Jacobs DM, Sandles LG, Leboit PE. Sebaceous carcinoma arising from Bowen's disease of the vulva. Arch Dermatol 1986;122:1191-3.

4. Tan 0, Ergen D, Arslan R. Sebaceous carcinoma on the scalp. Dermatol Surg 2006;32:1290-3.

5. Nelson BR, Hamlet KR, Gillard M, et al. Sebaceous carcinoma. J Am Acad Dermatol 1995; 33:1-15.

6. Shields JA, Demirci H, Marr BP et al. Sebaceous carcinoma of the ocular region: a review. Surv Ophthalmol 2005;50:103-22.

7. Rao NA, Hidayat AA, McLean IW, et al. Sebaceous carcinomas of the ocular adnexa: a clinicopathologic study of 104 cases, with five-year follow-up data. Hum Pathol 1982;13:113-22.
8. Kwitko ML, Boniuk M, Zimmerman LE. Eyelid tumors with reference to lesions confused with squamous cell carcinoma. I. Incidence and errors in diagnosis. Arch Ophthalmol 1963;69:693-7.

9. Ni C, Searl SS, Kuo PK, et al. Sebaceous cell carcinomas of the ocular adnexa. Int Ophthalmol Clin 1982;22:23-61.

10. Justi RA. Sebaceous carcinoma; report of case developing in area of radiodermatitis. AMA Arch Derm 1958;77:195-200.

11. Schlernitzauer DA, Font RL. Sebaceous gland carcinoma of the eyelid. Arch Ophthalmol 1976;94:1523-5.

12. Lemos LB, Santa Cruz DJ, Baba N. Sebaceous carcinoma of the eyelid following radiation therapy. Am J Surg Pathol 1978;2:305-11.

13. Hayashi N, Furihata M, Ohtsuki Y, et al. Search for accumulation of p53 protein and detection of human papillomavirus genomes in sebaceous gland carcinoma of the eyelid. Virchows Arch 1994;424:503-9.

14. Jain $\mathbf{P}$, Nanda A, Handa U, et al. FNA diagnosis of recurrent sebaceous carcinoma. Diagn Cytopathol 2006;34:124-6.

15. Stern RC, Liu K, Dodd LG. Cytomorphologic features of sebaceous carcinoma on fine needle aspiration. Acta Cyto/ 2000:44:760-4.

16. Doxanas MT, Green WR. Sebaceous gland carcinoma. Review of 40 cases. Arch Ophthalmol 1984;102:245-9.

17. Husain A, Blumenschein G, Esmaeli B. Treatment and outcomes for metastatic sebaceous cell carcinoma of the eyelid. Int J Dermatol 2008;47:276-9.

18. Harvey JT, Anderson RL. The management of meibomian gland carcinoma. Ophthalmic Surg 1982;13:56-61.

19. Spencer JM, Nossa R, Tse DT, et al. Sebaceous carcinoma of the eyelid treated with Mohs micrographic surgery. J Am Acad Dermatol 2001;44:1004-9.

20. Nunery WR, Welsh MG, McCord CD Jr. Recurrence of sebaceous carcinoma of the eyelid after radiation therapy. Am J Ophthalmol 1983;96:10-5.

21. Callahan EF, Appert DL, Roenigk RK, et al. Sebaceous carcinoma of the eyelid: a review of 14 cases. Dermatol Surg 2004;30:1164-8.

22. Yoon JS, Kim SH, Lee CS, et al. Clinicopathological analysis of periocular sebaceous gland carcinoma. Ophthalmologica 2007:221:331-9.

23. Saito A, Tsutsumida A, Furukawa $\mathrm{H}$, et al. Sebaceous carcinoma of the eyelids: a review of 21 cases. J Plast Reconstr Aesthet Surg 2008:61:1328-31.

24. Rizvi SAR, Maheshwari V. Advanced upper eyelid sebaceous gland carcinoma with deep orbital extension. J Surg Case Rep 2010;1:5 


\section{BMJ Case Reports}

This pdf has been created automatically from the final edited text and images.

Copyright 2011 BMJ Publishing Group. All rights reserved. For permission to reuse any of this content visit http://group.bmj.com/group/rights-licensing/permissions.

BMJ Case Report Fellows may re-use this article for personal use and teaching without any further permission.

Please cite this article as follows (you will need to access the article online to obtain the date of publication).

Varshney M, Alam K, Aziz M, Maheshwari V, Gaur K, Rizvi SAR. Sebaceous carcinoma of eyelid. BMJ Case Reports 2011;10.1136/bcr.04.2011.4050, date of publication

Become a Fellow of BMJ Case Reports today and you can:

- Submit as many cases as you like

- Enjoy fast sympathetic peer review and rapid publication of accepted articles

- Access all the published articles

Re-use any of the published material for personal use and teaching without further permission

For information on Institutional Fellowships contact consortiasales@bmjgroup.com

Visit casereports.bmj.com for more articles like this and to become a Fellow 